systematist appear in his careful descriptions, which will always retain their high value, even if in some cases his classification may have to be modified in future.

Martynov was able to trace backwards to earlier times the phylogeny of several groups of insects. He contributed a great deal to the knowledge of Permian Hemiptera, Mecoptera, Coleoptera, Odonata and other orders, and he described Phasmatodea and earwigs from Jurassic strata. The relations of these Permian and Jurassic forms to those of other countries were of special interest to him. He found close connexions between the Permian insects of Kansas and Russia, whilst the Jurassic fauna proved to be of an 'Angaran' type, with Indo-Australian relations.

There is no doubt that by Martynov's death palæo-entomology has suffered a severe loss and that his name and work will play an important part in research for a long time to come. F. E. ZEUNER.

\section{Mr. D. Baxandall}

Mr. David Baxandall, who recently retired from the position of deputy keeper at the Science Museum, passed away on January 10 at the age of sixty-three years, after a short illness.

Born on April 9, 1874, at Haworth, near Keighley, Mr. Baxandall received his early training at the Keighley Institute, where in 1891 he succeeded in winning a Royal Scholarship with which he proceeded to the Royal College of Science at South Kensington. Here he studied mechanics under Henrici and in 1894 obtained his first-class associateship in mechanics. He remained at the College for a further period during which he assisted Lockyer, until in 1898 he entered the Science Museum. During his first years at the Museum, he was employed in the Machinery and Inventions Division, but afterwards he was transferred to the Science Division, where he quickly developed a keen interest in early scientific instruments. He also studied the activities of early scientific instrument makers, and became a leading authority on this subject. Although Mr. Baxandall had a good knowledge of all kinds of scientific instruments, it was to astronomical, optical and mathematical instruments that he devoted his greatest attention, and it is chiefly due to his unremitting efforts that these subjects are so well represented in the Science Museum.

Mr. Baxandall was quiet and unassuming in manner, and although he was a fellow of the Royal Astronomical Society and of the Optical Society for many years, he was of such a retiring disposition that it was only with difficulty that he could be persuaded to speak at the meetings. He presented a number of papers on historical instruments and instrument makers before these Societies, and also contributed several articles to the "Encyclopædia Britannica".

By far the greater part of Baxandall's work, however, remains unpublished, for he collected together a large amount of valuable information on early instrument makers and their products, which he was hoping to prepare for publication, but unfortunately he was not able to complete the work. At the time of his retirement in 1934 he was deputy keeper in charge of the Science Division of the Science Museum, a position he had held for more than twelve years. He leaves a wife and two sons to mourn his loss, but he will be remembered with respect and affection by all who were privileged to know him as their friend.

\section{Prof. Gustav Jäger}

IN Gustav Jäger, whose death at seventy-three years of age occurred on January 21, Vienna has lost one of the last men who linked present-day physics with the classical period of the Viennese school as represented by the names of Stefan, Loschmidt and Boltzmann, and moreover one who had an unusually wide and all-round knowledge of physics. After several years of study in the laboratories of Stefan in Vienna and Helmholtz and Kundt in Berlin, he became assistant first to Stefan and later to Boltzmann. In 1905, he was appointed professor at the Technische Hochschule in Vienna, and then was called in 1918 to fill the chair of theoretical physics at the University of Vienna, which had formerly been held successively by Stefan, Boltzmann and Hasenöhrl. In 1920, Jäger changed this chair for the directorship of one of the University institutes of experimental physics. Generations of students have listened to his lecture courses, and greater still is the number of those who were introduced to the elements of mathematical physics through his "Theoretische Physik", published in the handy volumes of the "Sammlung Göschen", and distinguished by clarity as well as conciseness.

In his original contributions to physics, Jäger showed himself a true pupil of Loschmidt and Boltz. mann by his life-long interest in the problems of the kinetic theory of matter. Best known among his papers are probably those devoted to the develop. ment of a kinetic theory of 'ideal liquids', analogous to that of 'ideal gases'. That his occupation with technical problems bore fruit is shown, for example, by his contributions to the theory of aircraft construction; he was one of the earliest men of science who defended, on theoretical grounds, the possibility of heavier-than-air flying machines.

Jäger retired from his chair of physics in 1934, but as a member of the Vienna Academy of Sriences remained to the last in touch with scientific matters. His death is deplored by a great number of friends and colleagues, who will miss his amiable and cultured personality and his sound and balanced judgment.

F. A. P.

\section{WE regret to announce the following deaths :}

Mr. Thomas Gann, known for his explorations in Central America and his investigations of Maya archæology, on February 24, aged seventy years.

Dr. George Ellery Hale, For.Mem.R.S., honorary director of the Mount Wilson Observatory, Pasadena, California, on February 22, aged sixty-nine years. 